\title{
The role of CEOs in the sustainability of defined benefit pension plans
}

\author{
Joanne Horton $^{1}$ | Paraskevi Vicky Kiosse ${ }^{2}$ | Maria Koumenta ${ }^{3}$ (] | \\ Evisa Mitrou ${ }^{3}$
}

${ }^{1}$ Warwick Business School, The University of Warwick, Coventry, UK

${ }^{2}$ University of Exeter Business School, Exeter, UK

${ }^{3}$ School of Business and Management, Queen Mary University of London, London, UK

\section{Correspondence}

Maria Koumenta, Queen Mary, University of London, Mile End Road, London E1 4NS, UK. Email: m.koumenta@qmul.ac.uk

\begin{abstract}
The future of defined benefit (DB) pensions is a hotly debated topic in reward management. Drawing on agency and managerial power theories, the conditions under which CEOs can affect their sustainability have been examined. We show that when the CEO is a member of the same DB plan as their employees or when the CEO is both a member and a trustee of the plan, this affects the agency and power dynamics increasing the likelihood of these plans being retained. To address endogeneity concerns, we mimic randomisation using propensity score matching and the results continue to hold. Using the introduction of pension tax penalties as an exogenous shock on CEO self-interest, we find that it affects the propensity of DB plan closures. The study highlights the key role that CEO incentives play on pension-provision decisions and indicates how $\mathrm{HR}$ practitioners/regulators can harness CEO self-interest to safeguard the sustainability of DB pension plans.

KEYWORDS

agency, CEO incentives, defined benefit pension plans, managerial power
\end{abstract}

\footnotetext{
Abbreviations: CEO, chief executive officer; DB, defined benefit; DC, defined contribution; OECD, The Organisation for Economic Co-operation and Development; PSM, propensity score matching; TPR, the pensions regulator; UK, United Kingdom; US, United States; WPS, work and pensions select committee.
}

This is an open access article under the terms of the Creative Commons Attribution License, which permits use, distribution and reproduction in any medium, provided the original work is properly cited.

(c) 2020 The Authors. Human Resource Management Journal published by John Wiley \& Sons Ltd. 


\section{Practitioner notes}

\section{What is currently known?}

1. Pension provisions are associated with job attractiveness and employee commitment

2. Pensions are used by organisations as a signal of loyalty and commitment to the workforce

3. The future of pension provision in the form of defined benefit (DB) pension plans has been called into question

\section{What this paper adds?}

1. An empirical application of the principal-agent framework to multiagent settings

2. Evidence that the DB pension plan's survival rate significantly increases if the CEO is also a member

3. Evidence that when the CEO is a trustee of the plan, DB plans are more likely to be retained

\section{Implications for practitioners}

1. HR practitioners can shape managerial incentives such that they affect the sustainability of DB schemes

2. They can do this by ensuring that CEOs incentives are aligned with the rest of the employees

\section{1 | INTRODUCTION}

For many decades, pension plans have been recognised as an important pillar within the HR rewards literature. Within this body of work, the potential benefits of pension provision are well-documented. In particular, pensions are a pecuniary incentive that are expected to increase effort and prevent shirking through an alignment of interest (Lazear, 1979). It is also an element of the remuneration package that, in conjunction with other HR practices, enables organisations to improve the quality of their labour pool. Studies both in the UK and the US show that pension provision is associated with employer attractiveness (Loretto, White, \& Duncan, 2000; Tetrick, Weathington, Da Silva, \& Hutcheson, 2010). Based on the notion of reciprocity in the form of eliciting desirable employee behaviours, organisations further use pensions to increase employee commitment to the organisation and discourage turnover (Luchak, Pohler, \& Gellatly, 2008; Hales \& Gough, 2003, Taylor, 2009; Mitchell, 1982), as well as to prompt retirement when worker productivity is in decline (Gustman, Mitchell, \& Steinmeier, 1994). The availability of a pension scheme is also shown to affect employee sorting to organisations, such that it increases job attractiveness for those that have a long-term orientation toward the employer (McCarthy, 2006). In addition to these strategic HR goals, a pension also serves a symbolic function associated with signalling loyalty to employees and framing the employment relationship in open-ended terms (Dulebohn, Molloy, Pichler, \& Murray, 2009; Terry \& White, 2006).

Pensions are currently very topical. In a context of changing attitudes and practices in relation to entitlement and contributions, the future of pension provision has taken central stage in UK policy debates. Key to these discussions has been the survival capacity of what used to be the most common pension scheme operated by UK employers - defined benefit (DB) pension plan. DB pension plans in the UK have traditionally been set up in trusts, designed to safeguard scheme assets by separating them from those of the employer. Typically, the assets of the pension scheme are held in a trust. The board of trustees, which comprises of elected plan members, company or independent trustees, are responsible for ensuring the scheme is run in the interests of its members and adequately funded (2004 Pensions Act). Every scheme must appoint an auditor, an actuary and a fund manager 
(1995 Pensions Act). The Pensions Regulator (TPRc), established in 2004, protects members' benefits, and provides compensation to scheme members should their employer become insolvent via the Pension Protection Fund (2019) (TPR-a; TPR-b; Blake, 2003). Both employers and employees contribute to the pension fund which is invested in various assets including, inter alia, equities, property and government bonds. Pension's payments are paid out from the resulting investment income. A defining feature of final salary DB plans is that the income upon retirement is calculated based on a formula that links the pension to the salary being received at the time of retirement, or the highest earnings in the last years to retirement, thus going some way in guaranteeing the value of the final pension to the employee.

Against the backdrop of what has been described as a 'pension crisis' (Grady, 2013), the number of active members of DB plans dropped from $3.6 \mathrm{~m}$ in 2006 to $1.3 \mathrm{~m}$ in 2018 and $43 \%$ of schemes were closed to new members in 2018 (TPR 2018; Schröder, Muller-Camen, \& Flynn, 2014). Such closures come at a significant cost to employees, with recent reports suggesting that moving to a defined contribution (DC) plan (where the pension payout is unpredictable) is equivalent to an employee losing between $£ 200,000$ to $£ 300,000$ over the course of their retirement (Collinson, 2016) and delaying retirement by 2 years (Friedberg \& Webb, 2005). Despite these closures, around 10.5 million scheme members rely on DB pensions for their expected retirement income, confirming the importance of DB schemes for a significant proportion of the UK's labour force. Following the recent scandals of British Homes Stores and Carillion, and the high profile industrial dispute between UK university staff and their employers over the sustainability of the sector's DB scheme, the UK Government is considering whether suitable incentive structures and enforcement mechanisms could be implemented to increase the likelihood that DB schemes will be sustainable (Hughes, 2018). The debates surrounding the future of DB plans are not unique to the UK. Notably companies terminating or freezing to new entrants include Boeing, UPS, American Airlines and General Electric. But while studies document the increasing prominence of DC plans over their DB counterparts, DB coverage still remains relatively high. According to a recent OECD study, DB schemes represent a significant part of the pensions landscape in terms of both members and assets in 26 OECD countries. In some countries, namely Canada, Korea, Luxembourg, Mexico, the Netherlands, Portugal, Spain, Turkey and the UK, there were more members in DB than DC plans (OECD, 2016).

Existing research on the reasons for closing DB plans associates such closures with accounting reforms (Beaudoin, Chandar, \& Werner, 2010) and pension plan characteristics (Rauh, Stefanescu, \& Zeldes, 2013; Rauh \& Stefanescu, 2009). Within the employment relations literature and in the context of unionised workplaces, research on the presence of employee representatives on pension boards has produced mixed results in their ability to prevent scheme closures (Sayce, Weststar, \& Verma, 2014; Verma \& Weststar, 2011). Notably absent within these literatures is a consideration of how the agency power that top executives can exercise in pension plan closure decisions can impact a firm's propensity to continue supplying DB plans. We respond to these debates by investigating whether CEOs can have such an effect and under what conditions. Our theoretical assumptions are drawn from the literature on incentives and more specifically the principal-agent framework, which we extend and apply to multi-agent settings as well as insights from managerial power theory and the literature on CEO duality. In particular, we argue that CEO membership of the DB plan will make it likely that CEOs will use their power over the trustee board to negotiate pension arrangements that are in their favour. While this process is likely to give rise to CEO opportunism and aggravate the agency problems between CEOs and shareholders, CEO's preferences become more closely aligned with those of the employees. In the empirical analysis, we use UK data to investigate whether CEO membership of the DB plan differentially affects the probability of the plan becoming subject to two forms of closure: closed to new entrants followed by a cap on final salary benefits (partial closure) and closed to new entrants and existing members (full closure). To further assess the robustness of our analysis and to complement the studies on employee representatives as trustees (e.g. Verma \& Weststar, 2011; Weststar \& Verma, 2007), we examine whether the survival rates of the DB plans differ if the CEO is a member of the main DB plan and also a trustee, as this potentially allows the CEO to exert even greater power over closure decisions. 
Our sample consists of all UK listed firms that sponsored DB plans during the period 1999-2013, a total of 322 firms. We employ a duration hazard research design, which models the cause-specific hazards of a pension closure and thus predicts the survival rate of the DB plan in the next period, conditional on the CEO being a member of the main DB plan. To ensure confounding variables are not biasing our results, we supplement this analysis using propensity score matching where we mimic randomization by using a sample of firms whose CEO is a scheme member that is comparable on all observed covariates to a sample of firms whose CEO is not a member of the DB plan. Finally, we use the introduction of tax penalties on pension savings as an exogenous shock on CEO selfinterests which potentially may affect the propensity of CEOs to close the DB plans. Our main contribution lies in extending the conventional principal-agent framework to multiagent settings and in empirically showing that the spill-over effects of incentive arrangements pertaining to pension provisions are the co-alignment of the preferences of CEOs and employees and the misalignment of the shareholder interests and those of the CEO. Given the central role that pension provision plays within rewards management and the current public policy direction toward avoiding further scheme closures, our findings make an important empirical contribution to the HR community, trade unions and policy-makers as they endeavour to put in place incentive structures to increase the likelihood of the remaining DB plans to survive.

\section{2 | LITERATURE REVIEW}

Principal-agent frameworks describe the conflictual relationship between the interests of principals and agents based on assumptions about self-interest, rent-seeking and goal-conflict (Alchian \& Demsetz, 1972; Ross, 1973). What follows is the design of incentive structures that aim to address the agency costs emerging from the transactions of these parties (Jensen \& Meckling, 1976). Central within this literature is the notion that 'optimal contracting' can be achieved through the use of compensation mechanisms to curb agent opportunism and mitigate moral hazard risks. However, the extent to which contracting can address interest misalignment has been challenged within the agency and executive incentive literatures (Cuevas-Rodrigez et al., 2012; Grabke-Rundell et al., 2002; Pepper, Gore, \& Crossman, 2013). A key theme within these accounts is the consideration of ways in which the design of the incentive structures distorts rather than promotes convergence of the principal-agent interests, thus enabling agents to engage in self-serving behaviours. Such distortions can be particularly prevalent in multiple agent settings where the principal contracts with two agents and incentive systems are such that they can be manipulated to promote agent collusion (Demski \& Sappington, 1984; Laffont \& Martimort, 2009; Strausz, 1997).

CEO membership of DB plans has the potential to alter managerial incentives to this effect. For instance, Cadman and Vincent (2015) find between 2006 and 2012 40\% of the CEOs are members of the firms DB plan in the US and the benefits accruing to CEOs from their membership are significant with the average pension plan value of almost $\$ 7.5$ million which constitutes $23 \%$ of the CEO's total wealth held in the firm. In the UK, the annual increment of CEO DB pension plan value for FTSE 100 firms was 15\% in 2012 (Clark \& Peacock, 2013). Under a DB plan, the firm promises to pay the employee a fixed benefit from retirement until death. When the fund is in deficit, as has been the case with many plans since the beginning of our sample period, it is possible that the firm will consider closing the main DB plan thus creating a wealth transfer from employees to shareholders. The shareholders benefit because closing the pension plan shifts the future pension risk onto employees and reduce the firm's pension costs (de Thierry, Lam, Harcourt, Flynn, \& Wood, 2014). In contrast, for employees the closure of their DB plan, ceteris paribus, significantly reduces their retirement benefits and shifts investment risk to them as a DC option is generally offered in lieu of a DB plan. Given that an important institutional parameter of pension plans is that CEOs can be members of the same plan as other employees and also responsible for closure decisions, a multiagent setting is created whereby the agency dynamics are 
such that goal conflict between CEOs and shareholders can emerge. As rational utility maximisers, CEOs are likely to be incentivised to maintain these plans since their interests are more closely aligned with those of other agents within the organisation, rather than the principal's, as initially intended. Studies, for example, find empirical support for a three-tier agency model whereby principals collide with agents against the interests of shareholders when their preferences are more tightly aligned (Conyon \& He, 2004), while others show that DB plans with many senior employees as members are better funded, with annual contributions exceeding those required by law (Anantharaman \& Lee, 2014; Asthana, 1999). Based on these insights, we propose the following:

Proposition 1a: Firms whose CEOs are members of the firm's main DB plan on the same terms as other employees are less likely to fully close the main DB plan.

If the plan is fully closed, the expected effects on the firm's DB plan are straightforward; the members of the plan, including the CEO, will normally be worse off since they lose their vested interest. However, if the firm's pension plan is partially closed the direct effects on the CEO's plan are not clear. If there are further curtailments due to the partial plan closure, then CEOs will be worse off. For example, in most cases after a partial closure, firms introduce a cap on the final salary pension benefits of existing plan members to prevent large inequalities emerging between current employees who still accrue DB benefits and the new entrants who only accrue DC benefits. If the pension is partially closed and a salary cap is imposed, the reduction in future pension benefits is severe for CEOs as their salaries always exceed the cap level. Moreover, partial closures are typically the first stage before full closure of the DB plan. We would therefore expect CEO membership of the firm's main DB plan to have an impact on their decision to partially close the main DB plan. However, if a partial closure is not associated with any financial implications for the CEO, then the CEO will have no clear incentives to prevent a partial closure. As such, we form the following nondirectional proposition:

Proposition 1b CEO membership of the firm's main DB plan on the same terms as other employees will affect the decision to partially close the main DB plan.

Drawing on managerial power theory (Bebchuk \& Fried, 2004; Bebchuk, Fried, \& Walker, 2002), we further explore the conditions under which DB plans are likely to be maintained. At its core is the idea that CEOs have power over shareholders and board members to negotiate compensation arrangements that advance their interests. Such power can come from various sources including the CEO's dual role of being a member of the DB plan and also a member of the trustee board. CEO duality is commonly understood as a proxy for CEO power in that it creates opportunities for the CEO to exhibit self-serving behaviours and affect their compensation in ways that reflects their risk preferences (Boyd, 1994; Dalton \& Dalton, 2005; Grabke-Rundell et al., 2002; Krause, Semadeni, \& Cannella, 2014). For example, Bebchuk and Fried (2004) show how CEO control of the pay-setting process through board membership enhances their ability to extract rents. The UK's institutional setting pertaining to pension boards allows for CEO duality. DB trustees are responsible for determining the pension contributions, investment strategy and whether to operate or close the plan. Since not all trustees have to be independent of the firm, CEOs can also be a pension trustee. Consequently, when a CEO is a trustee, in addition to being DB plan member, it provides them with significant power to forward their own self-interest and thereby increase the probability of not closing, partially or fully, the firm's DB plan.

Proposition 2 Being both a trustee and a member of the firm's pension plan will negatively affect the CEO's decision to close the main $D B$ plan. 


\section{3 | RESEARCH DESIGN}

We employ a duration hazard model to examine whether CEO pension membership is associated with the firm's decision to close the main DB plan. We estimate the model using the proportional likelihood estimation developed by Cox (1972). A key strength of our approach vis-à-vis logistic or probit regression techniques is its dynamic nature, which allows us to consider the entire time period preceding the event (Chen, Lin, \& Zhou, 2012; Henebry, 1996). To implement the hazard model, we define the duration of interest starting with the first year of our sample period or the first year the firm appears during our period (whichever is the earliest) ending with the year the DB plan is closed or the end of our sample period if the plan is still open. The detailed model specification can be found in Appendix A1.

We capture the 'hazard event' by constructing two variables: Hazard_Full which takes the value of 1 when the DB pension is fully closed and zero if it remains open; Hazard_Partial which takes the value of 1 when the DB pension is partially closed and zero if it remains open. To examine the role CEO membership in the main DB plan has on its survival rate, we include an indicator variable CEO_MainDB, which takes the value of 1 if the CEO is a member of the main DB plan, and zero otherwise. Based on Proposition 1a, we expect the coefficient on CEO_MainDB to be negative and significantly different from zero, indicating that CEO_MainDB is associated with a decrease in the hazard (an increase in the survival rate) of closing the DB plan. In relation to proposition $1 \mathrm{~b}$ if the CEO perceives a significant cost, due to the imposition of a salary cap or the eventual closure of the main DB plan, then we expect the coefficient on CEO_MainDB to be negative and significantly different from zero. Alternatively, if there are no perceived costs, the incentives of CEOs who are members of the main DB plan will not be significantly different to those CEOs who are not members and therefore we expect the coefficient on CEO_MainDB not to be significantly different from zero. Data on pension plan members are hand-collected from 'Pension Funds and Their Advisers', an annual publication which provides information for the major UK pension funds.

We include several control variables used in the existing literature that are related to the survival of the main DB plan. The first set captures the main DB plan characteristics: funding status (Funded); percentage of active employees (Active); pension plan size (Plan_Size) and salary cap (Salary_Cap). The second set captures firm-specific characteristics: knowledge intensive firms (Knowledge_Firms); percentage of independent directors (\%Independent_Directors); board diversity (Board_Diversity); average salaries (Average_Salary); unionization level (Union); leverage (Leverage); the standard deviation of cash flows (Cash_Flow_Volatility); profitability (Profitability); sales growth (Sales_Growth) and firm risk (Firm_Risk). The last set of controls captures CEO characteristics (Beaudoin et al., 2010): CEO tenure (CEO_Tenure), level of CEO equity wealth (CEO_Equity) and level of CEO direct compensation (salary and bonuses) (CEO_Direct_Compensation). We also include industry-fixed effects. All variables are lagged and measured at the end of the year prior to the closure. To mitigate the influence of outliers, we winzorise all continuous variables top and bottom at $1 \%$. Robust standard errors are clustered at firm level. Variable definitions and data sources are presented in Table A2 in the Appendix.

\section{4 | SAMPLE}

The initial sample includes all constituents of the FTSE All-Share index from 1999 (the first year for which firms provide information on the market value of the pension plans assets and liabilities) to 2013. Our sample period ends in 2013 due to changes to the limit of tax-deductible pensions which led firms to re-evaluate their overall pension compensation policy introducing bias into later analysis (Goh \& Li, 2015). We remove firms not sponsoring a DB plan and firms with a DB plan in another country. The final sample contains 322 unique firms. The research design excludes firm-year observations after the plan is partially or fully closed. The sample contains 2542 firm-year observations for the fully closed analysis and 1254 firm-year observations for the partially closed analysis. Information on DB plan provision by year is presented in Table A3 in the Appendix. 


\section{5 | RESULTS}

Table A4 in the appendix presents descriptive statistics for fully and partially closed plans in Panels A and B, respectively. Table 1 presents estimates of Equation (1) where the dependent variable is Hazard_Full in columns (1) and (2) and Hazard_Partial in columns (3) and (4). The coefficient on CEO_MainDB, for both the full closure (column 1) and partial closure (column 3), is negative and significant. The coefficient on CEO_MainDB is -1.236 $(p<0.001)$ in column (1) and $-0.270(p<0.1)$ in column (3), indicating the hazard of full (partial) closure in the next period is $71 \%$ (24\%) lower if the CEO is a member of the DB plan [the hazard ratio is equal to exp. $(-1.236)=0.291]$. The results confirm Proposition 1a. For Proposition 1b, the results provide evidence that CEO membership of the firm's main DB plan also influences their decision to partially close, as the hazard of partial closure is lower.

\section{6 | ROBUSTNESS CHECKS}

The main challenge with cross-sectional research designs is the possibility of biases arising due to a difference in the treatment outcome (i.e., DB plan closure or sustainability) between groups that received the treatment (i.e., CEOs who are members) and those that did not (i.e., CEOs who are not members). Since the difference in the treatment outcome between the two groups may be the result of characteristics that predict the treatment (e.g., firm policies, CEO preferences, etc.) rather than the treatment itself. Propensity score matching (PSM) uses information from a pool of units that do not participate in the intervention to identify what would have happened to participating units in the absence of the intervention ( $\mathrm{Li}, 2013$; Rosenbaum \& Rubin, 1983). By comparing how outcomes differ for participants relative to observationally similar nonparticipants, it is possible to estimate the effects of the treatment thereby adjusting for the endogenous nature of the DB plan closure decision.

Empirically, we proceed as follows. We use a one-to-one matched pair design to identify each firm that fully (partially) closed the main DB plan with a firm that retained their plan. Consistent with Vafeas and Vlittis (2018), we match on funding status (Funded), profitability (Profitability), size of the plan (Plan_Size), industry and year. Table 2 reports the estimates from the Cox proportional hazard model using the matched samples. Overall, we find our results are not sensitive to this specification; the coefficients on CEO_MainDB, for both the full closure (column 1) and partial closure (column 3) continue to be negative and significant.

We further test whether CEO self-interest is driving our results by exploiting a recent policy shock. Specifically, we examine the introduction of the Finance Act 2004, which came into effect 6 April 2006. Under the new regime, annual or lifetime allowances were introduced, and if members exceeded these allowances they face an additional tax burden. The 'lifetime allowance' is set by the UK Government and is the maximum value of benefits an individual can have across all their registered pension arrangements without tax penalties arising. While the 'annual allowance' is the maximum amount by which the value of an individual's pension savings across all the registered pension schemes may increase during each tax year without tax penalties arising.

This tax change serves as a natural experiment for the CEO self-interest proposition as it exogenously affects all CEO incentives in the context of pension provision. If CEO self-interest prevails then we would expect CEOs who are members of open DB plans before 2007 to be more likely to close them post-2007, as they will have no incentive to continue contributing to the main DB plan given the tax burden. If, however, CEOs decide to keep the plans open due to some other firm characteristics or policies, then we should not observe a change in their behaviour post 2007. We expect the tax change will incentivise CEOs, who are members of their firm's DB plan, to fully close but we expect no incentive to partially close the DB plan as it does not significantly change their tax burden. For nonmembers (the control group), we would not expect any change in behaviour.

Empirically, we proceed as follows. We introduce a new variable POST2007 which is equal to 1 for financial years ending in 2007 onward, and 0 otherwise. We then estimate a logit regression where the dependent variable is 
TABLE 1 Cox proportional hazard model for fully closed and partially closed DB plans

\begin{tabular}{|c|c|c|c|c|c|c|c|c|}
\hline \multirow[b]{3}{*}{ Variables } & \multicolumn{4}{|c|}{ Hazard_full } & \multicolumn{4}{|c|}{ Hazard_partial } \\
\hline & (1) & & (2) & & (3) & & (4) & \\
\hline & Coeff. & z-stat & Coeff. & z-stat & Coeff. & z-stat & Coeff. & z-stat \\
\hline CEO_MainDB & $-1.236^{* * *}$ & -3.83 & $-1.492^{* * *}$ & -3.68 & $-0.270^{*}$ & -1.92 & $-0.477^{* *}$ & -2.56 \\
\hline CEO_MainDB*Funded & & & $-1.345^{* * *}$ & -2.74 & & & $-0.402^{*}$ & -1.94 \\
\hline \multicolumn{9}{|l|}{ Plan controls } \\
\hline Funded & $-0.499^{*}$ & -1.91 & $-0.632^{* *}$ & -2.22 & -0.109 & -0.68 & -0.333 & -1.52 \\
\hline Active & -0.883 & -1.33 & -0.957 & -1.47 & $0.514^{*}$ & 1.74 & $0.549^{*}$ & 1.85 \\
\hline Plan_Size & $-0.250^{* *}$ & -2.33 & $-0.254^{* *}$ & -2.36 & -0.060 & -1.16 & -0.057 & -1.09 \\
\hline Salary_Cap & 0.031 & 0.11 & 0.051 & 0.17 & -0.314 & -0.85 & -0.293 & -0.80 \\
\hline Partially_Closed & 0.200 & 0.60 & 0.176 & 0.53 & & & & \\
\hline
\end{tabular}

Firm controls

$\begin{array}{lllllllll}\text { Knowledge_Firms } & -9.353^{* *} & -2.01 & -9.533^{* *} & -2.01 & 1.582 & 0.79 & 1.480 & 0.74 \\ \text { \% Independent_Directors } & 2.510^{* * *} & 4.48 & 2.566^{* * *} & 4.51 & -0.501 & -0.82 & -0.481 & -0.79 \\ \text { Board_Diversity } & -0.156 & -0.24 & -0.157 & -0.24 & -0.285 & -0.85 & -0.286 & -0.85 \\ \text { Average_Salary } & 13.620 & 1.10 & 13.650 & 1.11 & 2.562 & 0.47 & 3.124 & 0.57 \\ \text { Union } & -1.780 & -1.03 & -1.776 & -1.03 & -1.358 & -1.64 & -1.467^{*} & -1.78 \\ \text { Leverage } & 1.704^{* *} & 2.19 & 1.727^{* *} & 2.18 & -0.431 & -1.01 & -0.465 & -1.09 \\ \text { Cash_Flow_Volatility } & 12.370^{* * *} & 2.65 & 12.430^{* * *} & 2.67 & -0.081 & -0.04 & -0.013 & -0.07 \\ \text { Profitability } & 0.010 & 0.01 & -0.010 & -0.01 & -0.187 & -0.65 & -0.210 & -0.72 \\ \text { Sales_Growth } & -0.445 & -0.50 & -0.424 & -0.47 & 0.001 & 0.00 & 0.020 & 0.08 \\ \text { Firm Risk } & -0.234 & -0.56 & -0.233 & -0.55 & 0.193 & 0.64 & 0.161 & 0.53\end{array}$

CEO controls

\begin{tabular}{lllllllll} 
CEO_Tenure & 0.048 & 1.61 & 0.048 & 1.59 & 0.016 & 0.91 & 0.017 & 0.96 \\
CEO_Equity & 0.193 & 0.33 & 0.174 & 0.29 & 0.196 & 0.86 & 0.238 & 1.04 \\
CEO_Direct_Compensation & $1.946^{* * *}$ & 2.94 & $1.917^{* * *}$ & 2.91 & 0.333 & 0.88 & 0.392 & 1.03 \\
\hline Observations & 2278 & & 2278 & & 1245 & & 1245 & \\
\hline Pseudo $R^{2}$ & 0.111 & & 0.114 & & 0.017 & & 0.018 \\
\hline
\end{tabular}

${ }^{* * *} p<0.01,{ }^{* *} p<0.05,{ }^{*} p<0.1$.

Hazard_Full and our variable of interest is the interactive variable CEO_MainDB*POST2007. We are unable to explicitly test Hazard_Partial however, as the majority of CEOs in this sample opted-out of firm's DB plans following the tax change announcement - thereby eliminating their tax burden - making pre and post-model inferences difficult. Table 3 reports the Hazard_Full results. We find post-2007, CEO propensity to close the scheme changes (columns 1 and 2). Specifically, CEOs who are members of the main DB plan pre-2007 are less likely to close the scheme, as the coefficient on CEO_MainDB is significantly negative $(-2.146, p<0.05)$; however, post-2007 the coefficient on CEO_MainDB*POST2007 is positively significant (1.076, $p<0.05$, Column 2), indicating CEOs are incrementally more likely to close the main DB plan following the exogenous shock. 
TAB LE 2 Propensity score matching for fully closed and partially closed DB plans

\begin{tabular}{|c|c|c|c|c|c|c|c|c|}
\hline \multirow[b]{3}{*}{ Variables } & \multicolumn{4}{|c|}{ Hazard_full } & \multicolumn{4}{|c|}{ Hazard_partial } \\
\hline & (1) & & (2) & & (3) & & (4) & \\
\hline & Coeff. & z-stat & Coeff. & z-stat & Coeff. & z-stat & Coeff. & z-stat \\
\hline CEO_MainDB & $-1.712^{* * *}$ & -4.07 & $-2.171^{* * *}$ & -3.40 & $-0.241^{*}$ & -1.82 & $-0.416^{* *}$ & -2.20 \\
\hline CEO_MainDB*Funded & & & $-1.744^{* * *}$ & -3.16 & & & $-0.446^{* *}$ & -2.03 \\
\hline \multicolumn{9}{|l|}{ Plan controls } \\
\hline Funded & -0.591 & -1.57 & $-0.827^{*}$ & -1.90 & -0.207 & -0.84 & $-0.403^{*}$ & -1.78 \\
\hline Active & $-1.338^{*}$ & -1.85 & $-1.391^{*}$ & -1.91 & $0.567^{*}$ & 1.81 & $0.600^{*}$ & 1.91 \\
\hline Plan_Size & $-0.256^{*}$ & -1.77 & $-0.258^{*}$ & -1.76 & -0.091 & -1.58 & -0.087 & -1.50 \\
\hline Salary_Cap & 0.497 & 1.34 & 0.551 & 1.51 & -0.228 & -0.61 & -0.218 & -0.59 \\
\hline Partially_Closed & 0.100 & 0.21 & 0.022 & 0.05 & & & & \\
\hline
\end{tabular}

Firm controls

$\begin{array}{lllllllll}\text { Knowledge_Firms } & -8.538 & -1.49 & -9.086 & -1.58 & 1.031 & 0.47 & 0.929 & 0.42 \\ \text { \% Independent_Directors } & 1.062 & 0.86 & 1.146 & 0.93 & -0.288 & -0.44 & -0.275 & -0.42 \\ \text { Board_Diversity } & 0.126 & 0.17 & 0.090 & 0.12 & -0.250 & -0.73 & -0.250 & -0.73 \\ \text { Average_Salary } & 22.870^{*} & 1.90 & 22.980^{*} & 1.98 & 6.046 & 0.96 & 6.438 & 1.04 \\ \text { Union } & 0.267 & 0.13 & 0.154 & 0.08 & -1.505^{*} & -1.77 & -1.600^{*} & -1.89 \\ \text { Leverage } & 1.132 & 1.13 & 1.050 & 1.04 & -0.435 & -0.99 & -0.459 & -1.04 \\ \text { Cash_Flow_Volatility } & 15.960^{* * *} & 3.37 & 15.660^{* * *} & 3.50 & -0.585 & -0.28 & -0.651 & -0.31 \\ \text { Profitability } & -0.186 & -0.24 & -0.192 & -0.26 & -0.016 & -0.05 & -0.032 & -0.10 \\ \text { Sales_Growth } & 0.234 & -0.25 & -0.126 & -0.14 & 0.175 & 0.74 & 0.199 & 0.84 \\ \text { Firm_Risk } & -0.649 & -1.19 & -0.554 & -1.02 & 0.337 & 1.00 & 0.307 & 0.91\end{array}$

CEO controls

\begin{tabular}{lllllllll} 
CEO_Tenure & 0.019 & 0.51 & 0.021 & 0.52 & 0.019 & 1.10 & 0.021 & 1.15 \\
CEO_Equity & 0.300 & 0.40 & 0.317 & 0.43 & 0.154 & 0.067 & 0.198 & 0.85 \\
CEO_Direct_Compensation & $2.703^{* * *}$ & 3.43 & 2.677 & 3.44 & 0.201 & 0.50 & 0.251 & 0.62 \\
\hline Observations & 2022 & & 2022 & & 1086 & & 1086 \\
\hline Pseudo R & 0.067 & & 0.067 & & 0.01 & 0.011 \\
\hline
\end{tabular}

${ }^{* * *} p<0.01,{ }^{* *} p<0.05,{ }^{*} p<0.1$.

\section{7 | THE ROLE OF CEO TRUSTEES}

Using the sample employed in the main analysis, we hand-collect the trustees' names from Pension Funds and Their Advisers to identify CEOs who are also trustees of the DB plan. Due to data availability, we were unable to collect data for the whole sample used in the main analysis, resulting in a sample of 725 firm-year observations for the partial closure and 1536 firm-year observations for the full closure analysis. We construct an indicator variable, CEO_Trustee, if the CEO is a trustee of the DB plan. All other variables are as previously defined. Descriptive statistics for the main variables of interest are reported in Table A5 in the Appendix. Table 4 reports the findings of the Cox model. The coefficient on CEO_Trustee in column (1) is $-0.681(p<0.001)$, suggesting a CEO who is a 
TABLE 3 Exogenous shock: Logit model examining the role of changes in lifetime tax allowance

\begin{tabular}{|c|c|c|c|c|}
\hline \multirow[b]{3}{*}{ Variables } & \multicolumn{4}{|l|}{ Full closure } \\
\hline & \multicolumn{2}{|l|}{ (1) } & \multicolumn{2}{|l|}{ (2) } \\
\hline & Coeff. & z-stat & Coeff. & z-stat \\
\hline CEO_MainDB & $-1.314^{* * *}$ & -3.72 & $-2.146^{* *}$ & -2.02 \\
\hline POST2007 & $2.537^{* * *}$ & 4.95 & $2.273^{* * *}$ & 3.93 \\
\hline CEO_MainDB*POST2007 & & & $1.076^{* *}$ & 2.77 \\
\hline \multicolumn{5}{|l|}{ Plan controls } \\
\hline Funded & $-0.750^{* * *}$ & -2.58 & $-0.745^{* *}$ & -2.57 \\
\hline Active & -0.936 & -1.23 & -0.953 & -1.26 \\
\hline Plan_Size & $-0.262^{* *}$ & -2.43 & $-0.257^{* *}$ & -2.42 \\
\hline Salary_Cap & 0.028 & 0.09 & 0.016 & 0.05 \\
\hline Partially_Closed & 0.283 & 0.76 & 0.298 & 0.80 \\
\hline
\end{tabular}

Firm controls

\begin{tabular}{|c|c|c|c|c|}
\hline Knowledge_Firms & $-9.918^{* *}$ & -1.98 & $-9.942^{* *}$ & -1.99 \\
\hline \%Independent_Directors & $2.510^{* * *}$ & 3.13 & $2.513^{* * *}$ & 3.14 \\
\hline Board_Diversity & 0.011 & 0.02 & -0.018 & -0.03 \\
\hline Average_Salary & 15.920 & 1.51 & 16.180 & 1.53 \\
\hline Union & -1.614 & -0.86 & -1.606 & 0.86 \\
\hline Leverage & $1.951^{* * *}$ & 2.62 & $1.913^{* * *}$ & 2.62 \\
\hline Cash_Flow_Volatility & $12.770^{* *}$ & 2.06 & $13.100^{* *}$ & 2.09 \\
\hline Profitability & -0.286 & -0.43 & -0.308 & -0.47 \\
\hline Sales_Growth & -0.899 & -0.90 & -0.884 & -0.90 \\
\hline Firm_Risk & 0.114 & 0.22 & 0.143 & 0.28 \\
\hline \multicolumn{5}{|l|}{ CEO controls } \\
\hline CEO_Tenure & 0.051 & 1.45 & 0.051 & 1.46 \\
\hline CEO_Equity & -0.872 & -1.35 & -0.863 & -1.34 \\
\hline CEO_Direct_Compensation & 0.852 & 1.41 & 0.855 & 1.42 \\
\hline Constant & $-6.419^{* * *}$ & -4.66 & $-6.425^{* * *}$ & -4.49 \\
\hline Observations & 2334 & & 2334 & \\
\hline Pseudo $\mathrm{R}^{2}$ & 0.275 & & 0.276 & \\
\hline
\end{tabular}

${ }^{* * *} p<0.01,{ }^{* *} p<0.05,{ }^{*} p<0.1$.

trustee of the pension board reduces the hazard of partial closure by $49 \%$. For firms whose CEO is both a trustee and a plan member (CEO_Trustee ${ }^{*}$ CEO_MainDB) (column 3), the likelihood that the main DB plan will partially close is reduced by an additional $77 \%$ relative to a CEO who is only a trustee, with a coefficient of $-1.477(p<0.001)$. The results in column (4) suggest this decision is not dependent on the funding status of the pension fund, as both CEO_Trustee*Funded and CEO_MainDB*Funded are insignificant. When the plan is in deficit and the CEO is both a trustee and a member of the plan, the survival rate increases by $84 \%$. For full closure, the coefficient on CEO_Trustee is negative, but not significant under any specifications (columns 5-7), although the results continue to hold for CEO_MainDB. 
TABLE 4 Cox regression results on the role of trustees for fully closed and partially closed DB plans

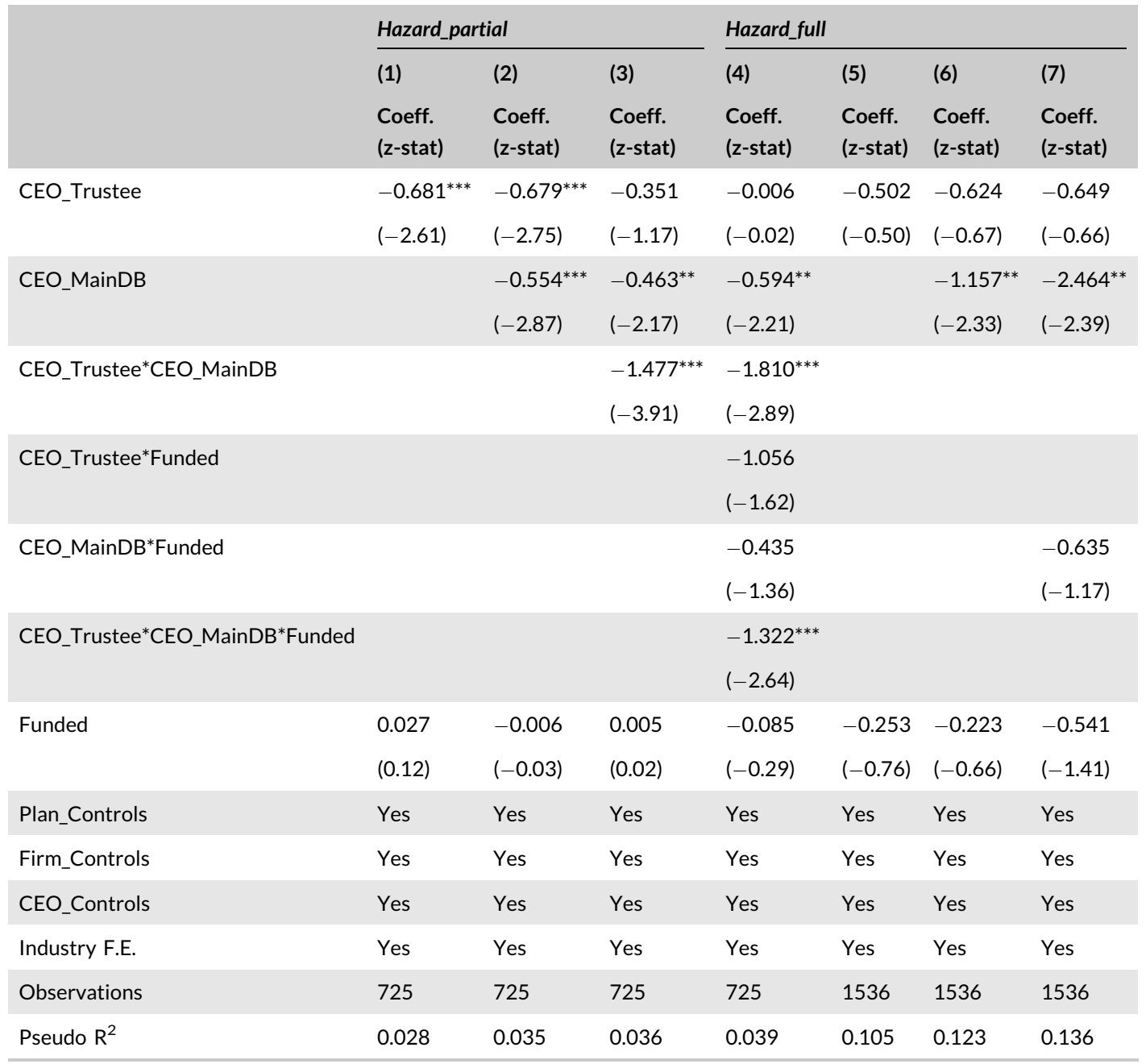

${ }^{* * *} p<0.01,{ }^{* *} p<0.05,{ }^{*} p<0.1$

\section{DISCUSSION AND CONCLUSION}

Despite pensions being an enduring feature of the reward package and empirically shown to play a part in meeting organisations' HR objectives, academic examination of the topic is limited. In the context of debates about the future of pension provision, we examine the conditions under which CEOs can affect the sustainability of DB pension plans. Overall, after controlling for firm, pension plan and other CEO characteristics, we find the main pension plan's survival rate significantly increases if the CEO is also a member - with the likelihood of full closure in the next period decreasing by $71 \%$ and that of partial closure decreasing by $24 \%$. Even if the main DB plan is in deficit, its survival rate significantly increases if the CEO is a member, with the likelihood of full (partial) closure decreasing by $77.5 \%$ (38\%). Our results demonstrate that CEO membership of the DB plan alters managerial incentives such that the interests of CEOs become aligned with those of employees rather than those of shareholders, thereby empirically contributing to the literature that seeks to model agent behaviours in multiagent settings (Demski \& Sappington, 1984; Laffont \& Martimort, 2009; Strausz, 1997). In our analysis, we retain the underlying assumptions of agency theory relating to moral hazard and the agent's utility being positively related to 
pecuniary incentives but posit that in a multiagent setting executive opportunism can be exploited such that DB pension plans are retained. Empirically, key strengths of our study rest on the consideration of observed confounding variables in the empirical analysis as well as the use of an exogenous regulatory shock that may alter CEO incentives in favour of closing the scheme. This latter exercise further reinforces our theoretical interpretation of CEO behaviour being motivated by agency and self-interest. However, we cannot rule out the possibility that such behaviour may also be informed by normative and affective motives. According to Sayce (2016), for example, in addition to rational motives (i.e., agency theory), normative and affective motives premised on the notion of fairness as well as looking after employees in the context of trustees' fiduciary responsibility influence CEO decisions in their role as trustees. These preferences can co-exist with rational motives and together can be a pull factor into trusteeship. Such an explanation could partly explain CEOs being less likely to close the scheme to new members (i.e., in addition to self-interest incentives). We further show that when the CEO is both a trustee and a member of the plan, partial closure is less likely to occur. In line with managerial power theory, we interpret this to result from the power that this duality affords to CEOs. Interestingly, we do not find this power to extend to full closures, possibly because duality makes the conflict of interest more salient to stakeholders and plan administrators, such that they intervene and prevent the CEO from blocking full closures.

In light of the recent scandals, the pressures for organisations to re-evaluate their approach to DB pension provisions have intensified. Given that pension provision 'reflects both the signalling and managing aspects of remuneration structures' (Terry \& White, 2006, p. 20) and the empirically documented negative consequences of terminating pensions for the psychological contract and the employment relationship more generally (Gough \& Hick, 2009; Lucero \& Allen, 1994), our findings are likely to be of interest to HR practitioners seeking to maintain DB plans as part of their employee reward package. The insights from this study can also assist members of remuneration committees to approach their pension provision policy strategically such that CEOs are incentivised to retain existing DB plans. While HR professionals are currently only minimally involved in the design of CEO remuneration packages (as the profession is typically underrepresented on remuneration committees), there are several voices within and outside the profession that advocate greater involvement (see, e.g., CIPD, 2019). To the extent that - via membership of remuneration committees - HR eventually becomes a more influential partner in the formulation of CEO pay strategy, our results show that HR professionals would probably be supportive of CEOs being placed on the same DB pension plan as other employees. Given the attractiveness of DB plans vis-à-vis their DC counterparts, HR can further use DB plans as a means of attracting and retaining highly sought-after CEOs.

Our findings are also important in the context of appointments of union trustees on pension boards, which are increasingly met with controversy and scepticism regarding their competency and effectiveness, thus leaving a void in terms of who will safeguard the interests of employee-members (Verma \& Weststar, 2011). From the unions' perspectives, our findings have implications in relation to how interest alignment between employee representatives and CEOs can be exploited in favour of protecting DB schemes. One avenue could be unions actively promoting CEO membership of these plans as well as CEO membership of trustee boards. Advocating to preserve and extend their coverage to other executives can also intensify pressures to protect existing plans.

Finally, our findings should also be of interest to policy makers as they continue to debate the type of regulation necessary to sustain the existing DB schemes and therefore protect scheme members, in light of the very high profile UK corporations who failed in their obligations to honour their pension promises. The White Paper issued by the Work and Pensions Select Committee (WPS) in March 2018, aimed at putting 'incentive structures in place to make it more likely that DB schemes would be sustainable and employers will honour their responsibilities' (Work and Pensions Select Committee, 2016). The Government responded by strengthening TPR's antiavoidance powers. Most notably was the introduction of a new criminal offence if a sponsoring firm acts wilfully or recklessly with the firm's pension plan (DWP, 2018; Thurley, 2020). While criminalization may act as a deterrent, some commentators were sceptical about the extent to which the 'wilful' or 'reckless' behaviour would be enforceable as ex post it would be difficult to distinguish between deliberate acts that put DB members' benefits at risk and poor investment outcomes flowing from the trustees' investment strategy (Thurley, 2020). Our findings speak to this 
issue by suggesting that a potentially complementary solution to ensuring the sustainability of DB schemes would be to try to ex ante incentivise CEOs by requiring them to be a member of the firm's main DB scheme offered to all other employees.

\section{9 | LIMITATIONS AND FURTHER RESEARCH}

There are some caveats to be noted with respect to this study. While PSM methodology and the exogenous policy shock approach allows us to address omitted variable bias to some extent, we still refrain from claiming causality. With respect to PSM, we can only match on observable characteristics, while a key assumption of using a policy shock is the absence of other interventions occurring during the period of interest that could have affected the outcome in the treatment group. While we are not aware of any changes specific to pension or corporate governance policies during this time it is possible that some other intervention that we do not observe indirectly affects closure decisions. We are also limited by the data availability in the analysis of the role of CEO trustees.

Further research could examine the impact on CEOs' compensation packages following the full (partial) closure of DB plans and the incentives any new packages, for example, cash in lieu payments and other remuneration in lieu of pensions, may have on CEO decisions. DB pension plan governance is of central importance to reward specialists and TPR recently issued a consultation on the 'Future of trusteeship and governance', which addressed a number of issues. In particular, TPR consulted on the role of professional, independent trustees and the merits of board diversity. In the response TPR noted that mandating a professional trustee for every pension board is currently not feasible; although TPR does have the power to appoint independent trustees. Moreover, TPR also reiterated their belief that diverse boards make better decisions compared with non-diverse boards and called for an industry working group to improve pension board diversity (TPR, 2020; TPR-c; TPR-d; Occupational Pension Schemes Regulations, 2005; Thurley, 2020). In this article, the focus is on CEOs who are also trustees. In light of TPR's consultation and ongoing developments in this area, it will be interesting for future research to examine the effect of trustee board characteristics, for example, composition and independence of trustee boards on ensuring effective governance and DB scheme sustainability. We believe this will bring further insights for both HR professionals and regulators.

\section{ACKNOWLEDGEMENTS}

We would like to thank seminar participants at the University of Manchester, University of Nottingham and WHU Germany for useful comments and suggestions in previous versions of the article.

\section{ORCID}

Maria Koumenta (D) https://orcid.org/0000-0003-1347-032X

\section{REFERENCES}

Alchian, A. A., \& Demsetz, H. (1972). Production, information costs, and economic organization. The American Economic Review, 62(5), 777-795.

Anantharaman, D., \& Lee, Y. G. (2014). Managerial risk-taking incentives and corporate pension policy. Journal of Financial Economics, 111(2), 328-351.

Asthana, S. (1999). Determinants of funding strategies and actuarial choices for defined-benefit pension plans. Contemporary Accounting Research, 16(1), 39-74.

Beaudoin, C., Chandar, N., \& Werner, E. M. (2010). Are potential effects of SFAS 158 associated with firms' decisions to freeze their defined benefit pension plans?. Review of Accounting and Finance, 9(4), 424-451.

Bebchuk, L., \& Fried, J. (2004). Pay without performance: The unfulfilled promise of executive compensation. Cambridge: Harvard University Press.

Bebchuk, L., Fried, J., \& Walker, D. (2002). Managerial power and rent extraction in the design of executive compensation. University of Chicago Law Review, 69, 751-846. 
Blake, D. (2003). The UK pension system: Key issues. Pensions, 8(4), 330-375.

Boyd, B. K. (1994). Board control and CEO compensation. Strategic Management Journal, 15(5), 335-344.

Cadman, B., \& Vincent, L. (2015). The role of defined benefit pension plans in executive compensation. European Accounting Review, 24(4), 779-800.

Chen, K., Lin, H., \& Zhou, Y. (2012). Efficient estimation for the Cox model with varying coefficients. Biometrika, 99(2), 379-392.

CIPD. (2019). RemCo Reform: Governing successful organisations that benefit everyone. London: Chartered Institute of Personnel and Development Report. Retrieved from https://www.cipd.co.uk/knowledge/strategy/governance/ reforming-remuneration-policy

Clark, L. \& Peacock, L. L. P. (2013). LCP FTSE 100 executive pension survey 2013.

Collinson, P. (2016). The scandalous changes to company pension schemes The Guardian. Retrieved from https://www. theguardian.com/money/blog/2016/aug/13/scandal-closure-company-pension-schemes

Conyon, M. J., \& He, L. (2004). Compensation committees and CEO compensation incentives in US entrepreneurial firms. Journal of Management Accounting Research, 16(1), 35-56.

Cox, D. R. (1972). Regression models and life-tables. Journal of the Royal Statistical Society: Series B, 34(2), $187-220$.

Cuevas-Rodríguez, G., Gomez-Mejia, L. R., \& Wiseman, R. M. (2012). Has agency theory run its course? Making the theory more flexible to inform the management of reward systems. Corporate Governance: An International Review, 20(6), 526-546.

Dalton, C. M., \& Dalton, D. R. (2005). Boards of directors: Utilizing empirical evidence in developing practical prescriptions. British Journal of Management, 16(s1), 91-97.

Demski, J. S., \& Sappington, D. (1984). Optimal incentive contracts with multiple agents. Journal of Economic Theory, 33(1), 152-171.

Dulebohn, J. H., Molloy, J. C., Pichler, S. M., \& Murray, B. (2009). Employee benefits: Literature review and emerging issues. Human Resource Management Review, 19(2), 86-103.

DWP. (2018). Protecting defined benefit pension schemes. Department for Work and Pensions.

Friedberg, L., \& Webb, A. (2005). Retirement and the evolution of pension structure. Journal of Human Resources, 40(2), 281-308.

Goh, L., \& Li, Y. (2015). Pensions as a form of executive compensation. Journal of Business Finance \& Accounting, 42(9-10), 1154-1187.

Gough, O., \& Hick, R. (2009). Employee evaluations of occupational pensions. Employee Relations, 31(2), $158-167$.

Grabke-Rundell, A., \& Gomez-Mejia, L. R. (2002). Power as a determinant of executive compensation. Human Resource Management Review, 12(1), 3-23.

Grady, J. (2013). Trade unions and the pension crisis: Defending member interests in a neoliberal world. Employee Relations, 35(3), 294-308.

Gustman, A. L., Mitchell, O. S., \& Steinmeier, T. L. (1994). The role of pensions in the labor market: A survey of the literature. Industrial and Labour Relations Review, 47(3), 417-438.

Hales, C., \& Gough, O. (2003). Employee evaluations of company occupational pensions: HR implications. Personnel Review, 32(3), 319-340.

Henebry, K. L. (1996). Do cash flow variables improve the predictive accuracy of a Cox proportional hazards model for bank failure?. The Quarterly Review of Economics and Finance, 36(3), 395-409.

Hughes, L. (2018). Pension crisis: Theresa May vows to target UK company pension abuse. Financial Times. Retrieved from https://www.ft.com/content/b20a2648-fe97-11e7-9650-9c0ad2d7c5b5

Jensen, M. C., \& Meckling, W. H. (1976). Managerial behavior, agency costs and ownership structure. Journal of Financial Economics, 3(4), 305-360.

Krause, R., Semadeni, M., \& Cannella, A. A., Jr (2014). CEO duality: A review and research agenda. Journal of Management, 40(1), 256-286.

Laffont, J. J., \& Martimort, D. (2009). The theory of incentives: The principal-agent model. Princeton and Oxford: Princeton University Press.

Lazear, E. P. (1979). Why is there mandatory retirement?. Journal of Political Economy, 87(6), 1261-1284.

$\mathrm{Li}, \mathrm{M}$. (2013). Using the propensity score method to estimate causal effects: A review and practical guide. Organizational Research Methods, 16(2), 188-226.

Loretto, W., White, P., \& Duncan, C. (2000). Something for nothing? Employees' views of occupational pension schemes. Employee Relations, 22(3), 260-271.

Lucero, M. A., \& Allen, R. E. (1994). Employee benefits: A growing source of psychological contract violations. Human Resource Management, 33(3), 425-446. 
Luchak, A. A., Pohler, D. M., \& Gellatly, I. R. (2008). When do committed employees retire? The effects of organizational commitment on retirement plans under a defined-benefit pension plan. Human Resource Management, 47(3), 581-599.

McCarthy, D. (2006). The rationale for occupational pensions. Oxford Review of Economic Policy, 22(1), 57-65.

Mitchell, O. S. (1982). Fringe benefits and labor mobility. Journal of Human Resources, 17(2), 286-298.

Occupational Pension Schemes (Independent Trustee) Regulations, 2005 Occupational Pension Schemes (Independent Trustee) Regulations (2005). Retrieved from http://www.legislation.gov.uk/uksi/2005/703/pdfs/uksiem_20050703_ en.pdf

OECD. (2016). OECD pensions outlook 2016. Paris: OECD Publishing. Retrieved from https://doi.org/10.1787/pens_outlook2016-en.

Pension Funds and their Advisers (1999-2013), London, UK: AP Information Services Wilmington PLC.

Pension Protection Fund. (2019). Retrieved from https://www.ppf.co.uk

Pepper, A., Gore, J., \& Crossman, A. (2013). Are long-term incentive plans an effective and efficient way of motivating senior executives?. Human Resource Management Journal, 23(1), 36-51.

Rauh, J. D., \& Stefanescu, I. (2009). Why are firms in the United States abandoning defined benefit plans?. Rotman International Journal of Pension Management, 2(2), 18-26.

Rauh, J. D., Stefanescu, W. E., \& Zeldes, S. (2013). Cost shifting and the freezing of corporate pension plans. Finance and Economics Discussion Series 2013-82. Washington, DC: Divisions of Research \& Statistics and Monetary Affairs Federal Reserve Board.

Rosenbaum, P., \& Rubin, D. B. (1983). The central role of the propensity score in observational studies for causal effects. Biometrika, 70(1), 41-55.

Ross, S. (1973). The economic theory of agency: The principal's problem. The American Economic Review, 63(2), 134-139.

Sayce, S. (2016). Public service motivation for executive pension trustees: A qualitative study. International Public Management Review, 17(1), 21-39.

Sayce, S., Weststar, J., \& Verma, A. (2014). The recruitment and selection of pension trustees: An integrative approach. Human Resource Management Journal, 24(3), 307-322.

Schröder, H., Muller-Camen, M., \& Flynn, M. (2014). The management of an ageing workforce: Organisational policies in Germany and Britain. Human Resource Management Journal, 24(4), 394-409.

Strausz, R. (1997). Collusion and renegotiation in a principal-supervisor-agent relationship. The Scandinavian Journal of Economics, 99(4), 497-518.

Taylor, S. (2009). Occupational pensions. In G. White \& J. Druker (Eds.), Reward management: A critical text. 2nd ed. Abingdon: Routledge.

Terry, N. G., \& White, P. J. (2006). Occupational pension schemes and their interaction with HRM. Human Resource Management Journal, 8(4), 20-36.

Tetrick, L. E., Weathington, B. L., Da Silva, N., \& Hutcheson, J. M. (2010). Individual differences in attractiveness of jobs based on compensation package components. Employee Responsibilities and Rights Journal, 22(3), 195-211.

The Pensions Regulator (TPR-a). Retrieved from https://www.thepensionsregulator.gov.uk/en/document-library/regulatoryguidance/trustee-guidance

The Pensions Regulator (TPR-b). Retrieved from http://www.thepensionsregulator.gov.uk/trustees

The Pensions Regulator (TPR-c). (2004). Retrieved from https://www.thepensionsregulator.gov.uk/en/media-hub/pressreleases/2020-press-releases/more-trustees-take-action-to-protect-savers-after-tpr-steps-up-communications

The Pensions Regulator (TPR). (2018). The DB landscape: Defined benefit pensions 2018. Retrieved from https://www. thepensionsregulator.gov.uk/-/media/thepensionsregulator/files/import/pdf/db-pensions-landscape-2018.ashx

The Pensions Regulator (TPR). (2020). Consultation response: Future of trusteeship and governance. Brighton: The Pensions Regulator.

de Thierry, E., Lam, H., Harcourt, M., Flynn, M., \& Wood, G. (2014). Defined benefit pension decline: The consequences for organizations and employees. Employee Relations, 36(6), 654-673.

Thurley, D. (2020). Briefing paper number CBP-4368, the pensions regulator: Powers to protect pension benefits. UK: House of Commons Library.

Vafeas, N., \& Vlittis, A. (2018). Independent directors and defined benefit pension plan freezes. Journal of Corporate Finance, 50, 505-518.

Verma, A., \& Weststar, J. (2011). Token presence or substantive participation? A study of labor trustees on pension boards. Journal of Labor Research, 32(1), 39-60.

Weststar, J., \& Verma, A. (2007). What makes for effective labor representation on pension boards? Labor Studies Journal, 32(4), 382-410.

Work Pensions Select Committee Report. (2016). Defined benefit pension schemes. London: House of Commons. 


\section{SUPPORTING INFORMATION}

Additional supporting information may be found online in the Supporting Information section at the end of this article.

How to cite this article: Horton J, Kiosse PV, Koumenta M, Mitrou E. The role of CEOs in the sustainability of defined benefit pension plans. Hum Resour Manag J. 2020;1-16. https://doi.org/10.1111/17488583.12329 